Original article

\title{
Recruitment behavior in stingless bees, Melipona scutellaris and M. quadrifasciata. II. Possible mechanisms of communication
}

\author{
Michael HrNCIR ${ }^{\mathrm{a}}$, Stefan JARAU ${ }^{\mathrm{a}}$, Ronaldo ZUCCHI ${ }^{\mathrm{b}}$, \\ Friedrich G. BARTH ${ }^{\mathrm{a} *}$ \\ a Universität Wien, Biozentrum, Institut für Zoologie, Abteilung Physiologie - Neurobiologie, \\ Althanstraße 14, A-1090 Wien, Austria \\ b Universidade de São Paulo, Faculdade de Filosofia e Letras, \\ Departamento de Biologia 14040-901 Ribeirão Preto, SP, Brazil
}

(Received 28 April 1999; revised 6 September 1999; accepted 22 September 1999)

\begin{abstract}
To find out what foragers of the stingless bees Melipona scutellaris and M. quadrifasciata actually do while recruiting nestmates to a food source we videotaped their behavior in the nest and simultaneously recorded the sounds and vibrations produced by them when returning from a rich food source. Neither temporal nor spectral characteristics of the sounds and vibrations correlated significantly with distance or direction to the food. Foragers motivated recruits to search for food at random by a " jostling run". The number of jostles by a forager correlates with the number of collecting bees. There was no correlation between the movements of a returning forager and either distance or direction to the feeder. "Zigzag flights", guiding flights and scent marking of foragers were excluded as a way to communicate the location of the food source. Aside from the indication of the mere existence of a food source the mechanisms by which foragers communicate its location are still obscure.
\end{abstract}

stingless bee / recruitment / mechanisms of communication / Melipona species / vibratory signaling

\footnotetext{
* Correspondence and reprints

E-mail: friedrich.g.barth@univie.ac.at
} 


\section{INTRODUCTION}

To broadcast information about a rich food source or a new nesting location is common behavior in highly social insects. It has been extensively studied in honeybees (Apis mellifera) since the pioneering work of Karl von Frisch [4] on the round- and the waggle-dance and their role in communicating distance and direction of a food source to recruits.

In stingless bees (Apidae; Meliponinae) there is great variation of recruitment- and communication mechanisms as originally shown by the pioneering work of Lindauer and Kerr [10] and later reviewed by Kerr [6] and by Nieh and Roubik [14]. In some species, foragers returning from a food source produce weak sounds thereby indicating the existence of a rich food source (Trigona silvestris). Other species use scent trails (Trigona spinipes) to guide their nestmates to a food source. Melipona scutellaris, M. quadrifasciata, and M. panamica were reported not to use such scent trails $[10,14]$, although foragers of $M$. panamica do deposit a scent beacon near a food source to help recruited bees with short distance (6 to $12 \mathrm{~m}$ ) orientation [12]. In addition, M. panamica is able to recruit nestmates to a food source not only indicating its distance and direction but even its height above the ground [14].

Upon returning to their colony, successful foragers of M. scutellaris, M. quadrifasciata, M. merillae [2], and M. panamica [14] produce sound pulses, thought to be important for their recruitment success. Such sounds were first recorded and analyzed by Esch and coworkers [2,3]. The duration of the individual sound pulses was found to correlate with the distance of a food source in M. merillae and M. quadrifasciata. Regarding the communication of direction Esch [2] observed a "zigzag flight" of the forager for the first part of the way from the hive to the food source, with recruited bees directly following. Nieh and Roubik [15] found similar correlations (regarding air- borne sound) for M. panamica. They distinguished sound pulses produced during the unloading of food from sound pulses produced thereafter ("dance sounds"). Whereas the duration of the first type of pulses correlated negatively with the height of the food source above the ground, the duration of the "dance sounds" correlated positively with its distance from the hive. For the communication of direction Nieh and Roubik [15] propose a hitherto unknown mechanism employed outside the hive. When analyzing the "dance" of the foragers of M. panamica in the hive in some detail, Nieh [13] found that those collecting at a poor food source turn at lower velocities than those collecting at rich food sources.

In our present study we examined possible mechanisms of communication in M. scutellaris and M. quadrifasciata. These species do not use scent trails to guide newcomers to a food source [10]. However, they are able to recruit nestmates and to indicate the direction of a food source whereas distance communication is rather inaccurate in both species [5]. Here we ask the following questions: (1) what are foragers doing in the nest when recruiting nestmates? (2) Is any parameter of the sounds and vibrations produced by successful foragers within the hive correlated with either the distance or the direction to a food source? (3) Do recruited bees follow a foraging guide directly to a food source? (4) Is there an indication for the use of scent marks [7, 8, 12]? (5) Which behavior do recruits show before leaving the hive for the food source?

\section{MATERIALS AND METHODS}

\subsection{Study site and colonies}

The experiments were carried out from September 1996 to February 1997 on the Ribeirão Preto Campus of the Universidade de São Paulo, Brazil. We used one colony of Melipona scutellaris and one colony of M. quadrifasciata. The colonies were kept in 
wooden boxes inside the laboratory with plastic entrance tubes ( $15 \mathrm{~mm}$ in diameter) inserted through the wall of the building (for further details see companion paper [5]).

\subsection{Food and marking of bees}

Sugar water scented with $3 \mu$ l essence of rosewood (Aniba rosaeodora)/ml solution was used at concentrations of $0.75 \mathrm{~mol} \cdot \mathrm{l}^{-1}$ and $1.5 \mathrm{~mol} \cdot \mathrm{l}^{-1}$ for training the bees and for the experiments, respectively. The bees were marked individually with a unique combination of two out of five different colors [4]. For further details see companion paper [5].

\subsection{Training of bees and experiments}

We trained three marked bees between 9 a.m. and 11 a.m. to a specific feeding station offering $0.75 \mathrm{~mol} \cdot \mathrm{1}^{-1}$ scented sugar water as described in Jarau et al. [5]. After a two hours break with the feeding station removed, the experiment proper began at 1 p.m. when the same feeder with $0.75 \mathrm{~mol} \cdot \mathrm{l}^{-1}$ sugar water was reinstalled at the training site of the morning. After injecting $5 \mathrm{ml}$ of the same sugar water into the hive's entrance tube we waited until all three foragers showed up at the feeder. Normally this took only a few minutes. We then started to videotape the behavior of the bees and to record the signals produced by foragers inside the hive (see Recording Box). After five minutes the feeding dish was replaced by a dish filled with $1.5 \mathrm{~mol} \cdot \mathrm{l}^{-1}$ sugar water. We then recorded for periods of five minutes with five minutes break in between for a total of 45 minutes. At the feeder the arrival times of the foragers and the numbers and arrival times of all newcomers were recorded. Newcomers were then captured and kept alive in a jar until the end of the respective experiment.

To investigate the behavior inside the hive and the signals produced by foragers returning from the food sources at different locations, we trained the foragers to a new site after 45 minutes, changing either distance or direction. We repeated the recording procedure for another 45 minutes, trained the foragers to a third site and recorded for another 45 minutes. We then removed the feeder and again recorded for five minutes to see if the foragers change their behavior under these conditions.

To correlate the behavior of the foragers and their signals to different distances of the food source we first trained foragers of M. scutellaris to a distance of $30 \mathrm{~m}$ (direction $\mathrm{NW}$ ), then to a distance of $70 \mathrm{~m}$ and finally to a distance of $140 \mathrm{~m}$. Foragers of $M$. quadrifasciata were first trained to a distance of $10 \mathrm{~m}$ (direction NW), then to distances of $30 \mathrm{~m}, 45 \mathrm{~m}, 70 \mathrm{~m}$, and $140 \mathrm{~m}$, respectively. To do the same with different directions we trained the bees to a food source at a constant distance of $30 \mathrm{~m}$ in the directions south-east, south and south-west (M. scutellaris) or north-west, west and south-east ( $M$. quadrifasciata), respectively.

\subsection{Recording box}

A wooden recording box between the nest box and the entrance/exit-tube (Fig. 1) was readily accepted by the bees as part of their hive. Its glass cover allowed us to videotape the foragers and their nestmates (Canon, Canovision EX1, Hi8) from above. Airborne sound signals were recorded with a microphone (Sony ECM-959DT) inserted into the recording box from the side and protected from the bees by a piece of mosquito net. An accelerometer (Brüel and Kjær, Type 4374) glued to the center of the cardboard bottom of the recording box at its underside was used to monitor substrate vibrations. The vibration signals were amplified using a charge amplifier (Brüel and Kjær, Type 2635), and recorded together with the airborne sound using both a DAT recorder (Sony TCD-D10) and the video camera. 


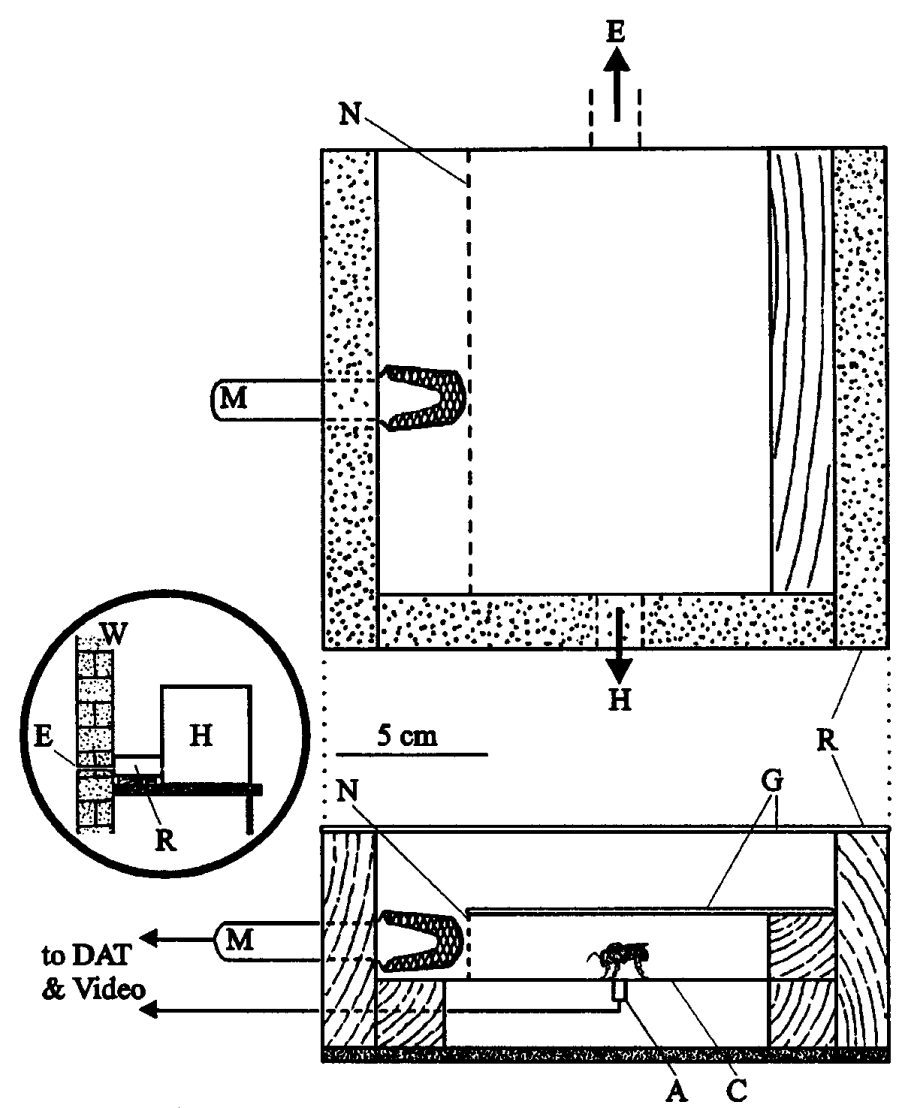

Figure 1. Recording box. To be able to record airborne sound and substrate vibrations a wooden box $(17 \times 15 \times 7 \mathrm{~cm})$ was placed between the hive and the entrance/exit tube (inset in circle), with a microphone inserted through one side and an accelerometer glued to its cardboard bottom. Both signal types were recorded using a DAT-recorder. The bees were videotaped from above and the mechanical signals additionally recorded on the audio track of the video tape recorder. $\mathbf{A}$, accelerometer; $\mathbf{C}$, cardboard; $\mathbf{E}$, exit/entrance; $\mathbf{G}$, sheets of glass; $\mathbf{H}$, hive; $\mathbf{M}$, microphone; $\mathbf{N}$, mosquito net; $\mathbf{R}$, registration box; $\mathbf{W}$, laboratory wall.

To get an estimate of the distortion of the signal along with its transmission from the vibrating bee through the cardboard to the accelerometer we examined the transmission properties of the cardboard bottom of the recording box. For this purpose we used a noise generator to drive a vibrator (Ling V 106, Royston - U.K.). The tip of the vibrator's pestle was glued perpendicular to the cardboard at different places (simulating different locations of vibrating bees) with a drop of bees wax (Fig. 2). At each location vibratory noise containing frequencies between $10 \mathrm{~Hz}$ and $2000 \mathrm{~Hz}$ was introduced into the bottom of the recording box. An accelerometer (Brüel and Kjær, Type 4375) attached to the base of the vibrator's pestle measured the actual vibratory input whereas the vibrations transmitted by the cardboard were measured using a LaserDoppler-Vibrometer (LDV; Polytec OFV 300 sensor head, Waldbronn-Germany) which pointed to the center of the cardboard where another accelerometer was attached 
and used for recording the bee's signals during the actual experiment. The noisy input signal and the LDV signal were digitized and stored on a PC. Fast-Fourier-Transformation (FFT) provided frequency spectra.
For each couple of vibratory input/substrate vibration output a transmission graph was calculated (Fig. 2) applying the programs DIA/DAGO and DIAdem (Gesellschaft für Strukturanalyse mbH, Aachen-Germany).
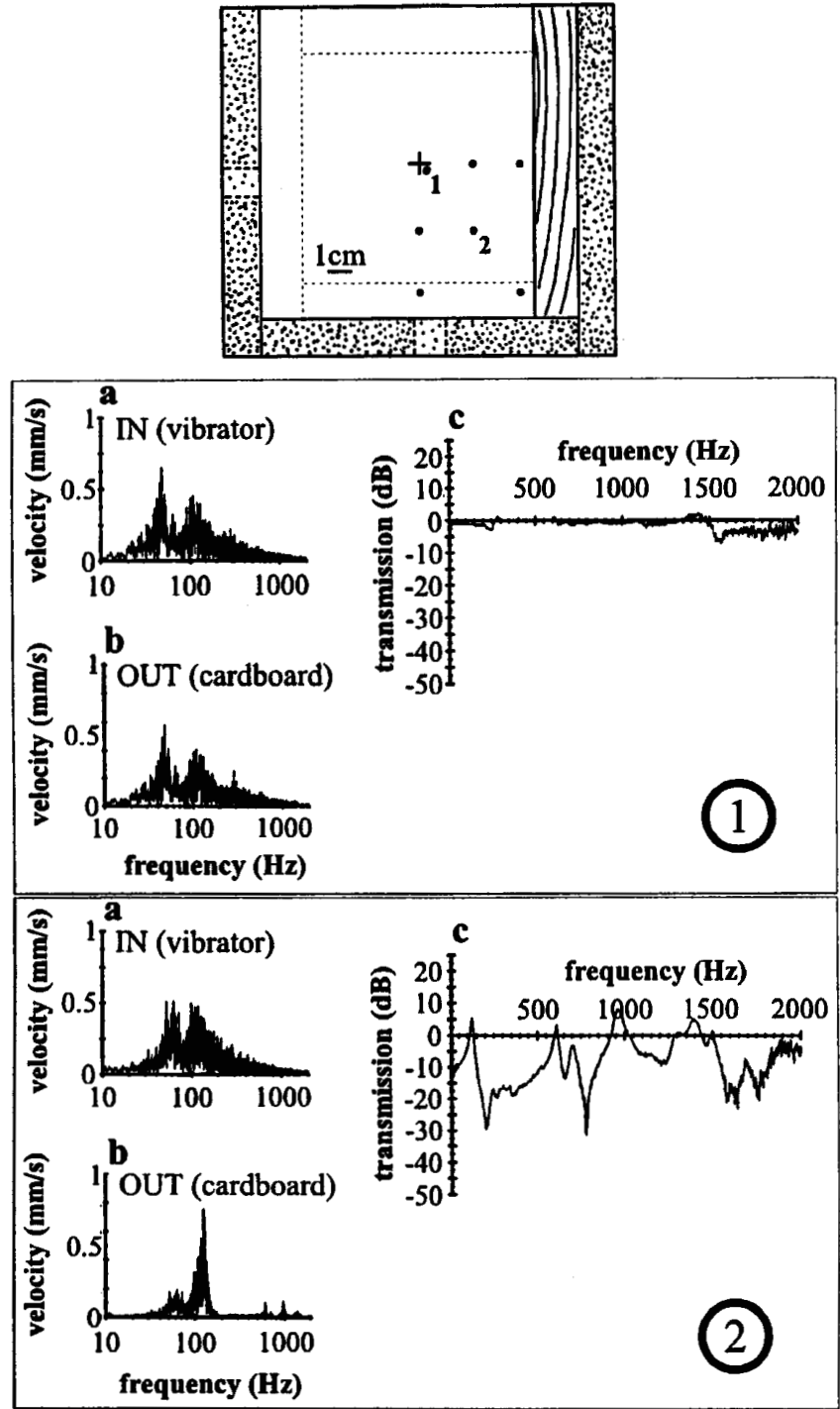

Figure 2. Mechanical properties of the recording box. Upper drawing: to test the vibration transmission of the cardboard bottom we applied a noise signal at seven different points (black dots) using an electromagnetic vibrator and measured the vibrations transmitted to the center (cross) with a laser doppler vibrometer. Panels 1 and 2 refer to measurements at points 1 and 2, respectively: (a) signal input, (b) transmitted vibration, and (c) transmission calculated from these two measurements. The signal is transmitted without major distortion only when applied close to the cardboard's center. 


\subsection{Signal analysis}

The recorded airborne sounds and substrate vibrations were digitized with an Analog-Digital-Converter (CED 1401, Cambridge Electronic Design Ltd.) and stored on a PC. The program Spike2 (Cambridge Electronic Design Ltd.) was used to obtain frequency spectra. The following signal parameters were analyzed: (i) the duration of the signal, (ii) the number and (iii) duration of the individual pulses, (iv) the duration of the intervals between the pulses and (v) the frequency content of the signals or of its constituent pulses. We compared the data for different feeding sites using KrustalWallis 1-Way Anova (significance level $p \leq 0.05)$. The statistics are based on the average of all values obtained for a specific parameter for each respective direction and distance. The correlation between the above mentioned parameters and distance or direction to the food source was quantified by regression analysis.

\subsection{Behavior outside the hive}

We observed the bees when they left the nest and when they arrived at the feeding stations. The close surroundings of the laboratory building allowed us to watch the flight of the bees from the nest exit up to a distance of $50 \mathrm{~m}$. Because of the low density of the vegetation of the study area (mainly grassland with some trees and shrubs) these observations were easy to do.

\subsection{Behavior inside the hive}

When analyzing the video tapes we distinguished foragers (marked bees trained to an experimental feeder before the start of an experiment), prospective recruits (marked bees later captured at the feeder during the experiment) and hive bees. We looked for the following parameters: locomotory behavior of the foragers, behavior of prospective recruits before leaving the hive, and interactions between foragers and prospective recruits or hive bees, respectively. The angles of the rotations occurring during the runs of the foragers and after having unloaded food were analyzed using the software Kreisgraphik 4 (oxalis Softwaresysteme für Wirtschaft und Wissenschaft $\mathrm{GmbH}$, 1998).

\section{RESULTS}

\subsection{Behavior outside the hive}

In more than 50 observation periods of the flight behavior of the bees directly at the hive entrance and in its near surroundings we never saw any kind of following behavior as described for M. scutellaris and M. quadrifasciata by Lindauer and Kerr [10] nor could we see the "zigzag flight" of a forager guide followed by a nestmate as described for M. quadrifasciata and M. merillae by Esch [2]. Foragers consistently flew in a more or less straight line to the experimental feeder. Recruits of M. scutellaris never reached the feeder together with a forager. Recruits of M. quadrifasciata arrived at the feeder together with foragers in only $16(5 \%)$ of the 330 observations.

For both species about 6000 approaches of foragers at an artificial food source were watched. In only rare cases (15 for $M$. scutellaris; 37 for M. quadrifasciata) we could observe bees interrupting their direct return back to the hive by a short rest on a bush or any other structure near the feeder. We do not know whether these bees were depositing scent marks.

\subsection{Behavior inside the hive}

\subsubsection{Foragers}

Before offering highly concentrated sugar water $\left(1.5 \mathrm{~mol} \cdot \mathrm{l}^{-1}\right)$ outside the hive we videotaped the recording box for 5 minutes with the foragers still collecting at a feeder with $0.75 \mathrm{~mol} \cdot \cdot^{-1}$ sugar water. Within these 
5 minutes the foragers did not show any kind of specific behavior nor did they produce any kind of sounds when entering the hive. The same behavior can be found after the removal of the feeder at the end of an experiment.

Jostling. As soon as a forager found and fed at an artificial food source with more concentrated sugar water $\left(1.5 \mathrm{~mol} \cdot \mathrm{l}^{-1}\right)$ it exhibited agitated zigzag running upon returning to the hive often colliding with nestmates both before and after the unloading of food. Two different kinds of this "jostling run" can be distinguished primarily based on the direction of movement of the hive bee relative to the direction of the movement of the forager (Fig. 3). We took 36 random samples of jostling runs for each bee species. There was no significant dif- ference in our findings between the two species (STUDENT- $t$-test, $p>0.05$ ).

In semi contact jostling forager and hive bee did not collide. The hive bee gave way (more or less at right angle to the running direction of the forager) to the running forager which did not obviously reduce its speed and altered its running direction only in $40 \%$ of the cases. Due to the limited resolution of our videos we can not say if there was any antennal contact between forager and hive bee.

In full contact jostling the forager collided with a nestmate (the forager bumped with its head into the nestmate) and displaced it. The hive bee moved more or less in the running direction of the forager. As a consequence of the collision the running speed of the forager was reduced by $60 \%$.

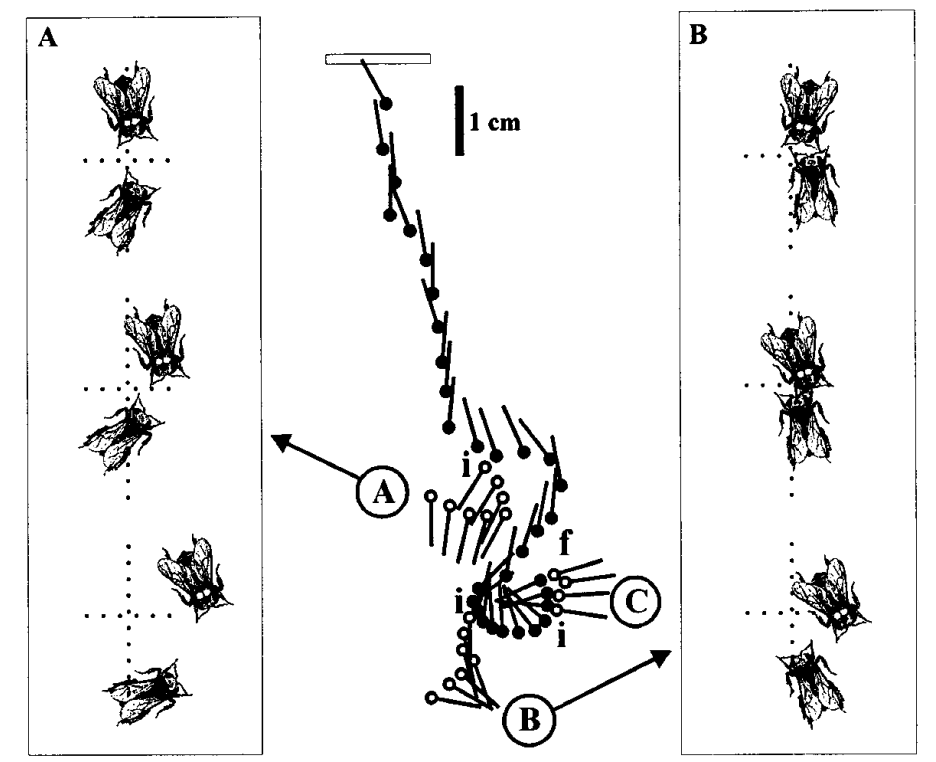

Figure 3. Two types of the "jostling run". Center panel: running path of a successful forager (black dot marks its head, the line its long axis) in the recording box after having collected at a food source $30 \mathrm{~m}$ away in the southeast of the hive. The position of the bees is shown at intervals of $0.04 \mathrm{~s}$. A semi contact jostling, $\mathbf{B}$ full contact jostling and $\mathbf{C}$ unloading of food. White bar marks the entrance of the hive, white dots symbolize hive bees; $\mathbf{i}$ initial position of a hive bee before jostling, $\mathbf{f}$ position of the same hive bee when taking up the food. The pictures to the left and right were taken from a video. They show details of the two types of jostling. The forager is marked with two white dots on its thorax. The hive bee is not marked. The position of the bees is shown at $0.04 \mathrm{~s}$ intervals relative to an imaginary spot (crossed dotted lines). 


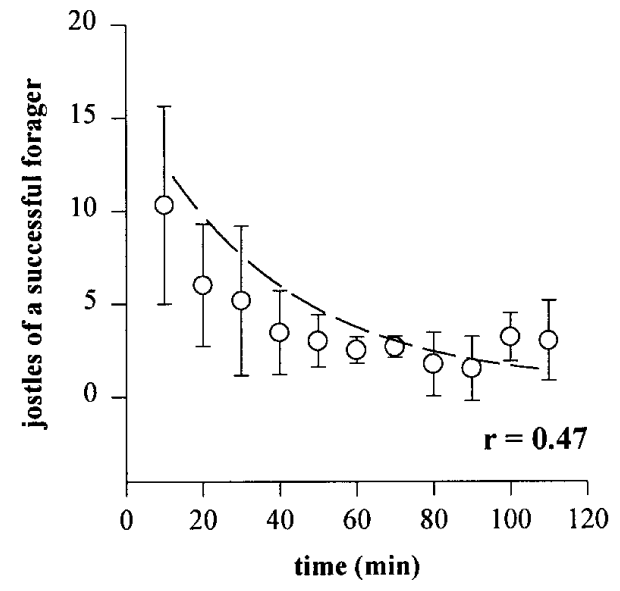

Figure 4. Exponential decrease $(r=0.47)$ of the number of jostles (mean $\pm 1 \mathrm{SD}$ ) of a successful forager with the duration of an experiment. Time 0 marks the injection of $1.5 \mathrm{~mol} \cdot \mathrm{l}^{-1}$ sugar water into the hive.

Furthermore the running direction of the forager changed in $75 \%$ of the cases.

To understand the functional meaning of the jostling we observed 120 randomly chosen entries of 10 different foragers of M. quadrifasciata into the hive. We found a higher "agitation" at the beginning of each experiment (about 10 jostles per entry). After about 30 minutes the jostling level of the foragers was about 3 jostles per entry. The number of jostles per entry decreased exponentially $(r=0.47)$ with the duration of the experiment (Fig. 4).

Running path. In both bee species under study the movement patterns of the foragers in the hive varied considerably. A bee collecting at a feeder might unload food directly at the hive entrance without even entering but run through our recording box with exaggerated turnings the next time (Fig. 5). For M. quadrifasciata we analyzed the paths taken by foragers within the hive $(N=6$, $n=64)$ in some detail. Clockwise and counterclockwise turning occurred equally often. No correlation could be found between the mean number nor the mean angle of turnings with the distance and the direction of the food source $(p>0.05$, Tab. I).

\subsubsection{Rotations}

After unloading their food foragers sometimes rotated on the spot clockwise or counterclockwise (in $34 \%$ of the observations in

\section{M. scutellaris}

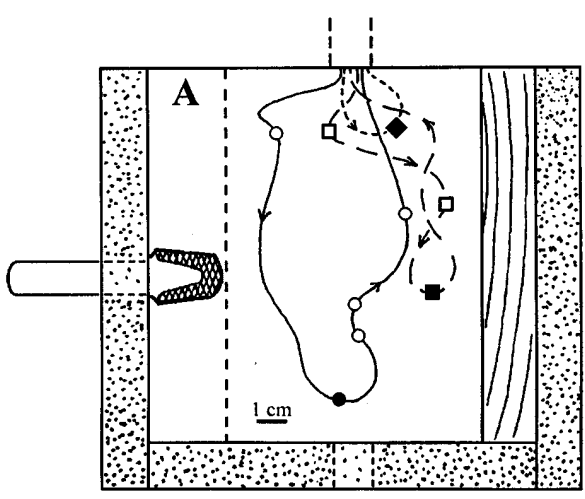

\section{M. quadrifasciata}

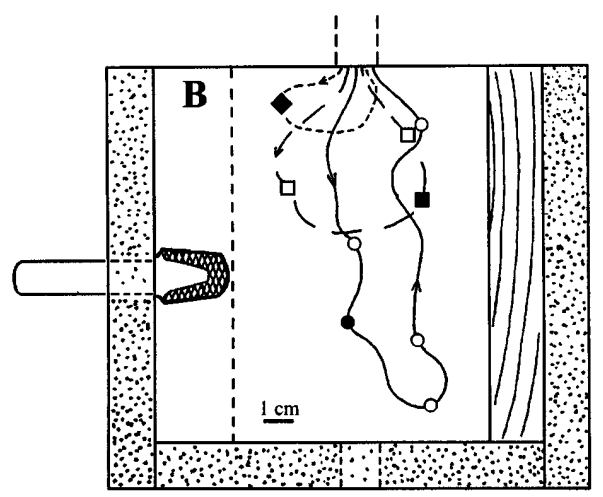

Figure 5. Three running traces in the registration box of foragers upon their return to the hive. Direction given by arrows. A M. scutellaris (collecting at a food source $30 \mathrm{~m}$ southwest of the hive) and B M. quadrifasciata (collecting at a feeder $140 \mathrm{~m}$ west of the hive). $\bigcirc, \square$ sites of contacts with hive bees; $\boldsymbol{\bullet}, \boldsymbol{\square}, \boldsymbol{\text { sites }}$ of food transmission. 
Table I. Number and size of turns in the running pattern of a successful forager of M. quadrifasciata upon returning to the hive in relation to the distance and the direction of a food source from the hive. The values given for the turning angle are the angle (and the radius) of the mean difference vector (difference between original and final position of the bee) $\pm 1 \mathrm{SD}$ and the mean $\pm 1 \mathrm{SD}$ for the number of turns. Food source distances: $10 \mathrm{~m}(N=2, n=6), \mathbf{3 0} \mathbf{~ m}(N=3, n=5), \mathbf{4 5} \mathbf{~ m}(N=2, n=7)$, $70 \mathbf{~ m}(N=4, n=7)$ and $\mathbf{1 4 0} \mathbf{~ m}(N=3, n=8)$; food source directions: north-west $(N=2, n=10)$, west $(N=4, n=15)$ and south-east $(N=2, n=6)$. The amount of turning and the number of turns do not significantly correlate with either distance or direction of the food source $(p>0.05)$.

\begin{tabular}{|c|c|c|c|c|c|c|c|c|}
\hline \multirow{2}{*}{$\begin{array}{l}\text { parameters } \\
\text { of turning }\end{array}$} & \multicolumn{5}{|c|}{ distance to food source } & \multicolumn{3}{|c|}{ direction to food source } \\
\hline & $10 \mathrm{~m}$ & $30 \mathrm{~m}$ & $45 \mathrm{~m}$ & $70 \mathrm{~m}$ & $140 \mathrm{~m}$ & NW & $S$ & SE \\
\hline angle & $\begin{array}{c}62^{\circ} \pm 23^{\circ} \\
(0.634)\end{array}$ & $\begin{array}{c}45^{\circ} \pm 56^{\circ} \\
(0.322)\end{array}$ & $\begin{array}{c}56^{\circ} \pm 37^{\circ} \\
(0.416)\end{array}$ & $\begin{array}{c}68^{\circ} \pm 43^{\circ} \\
(0.737)\end{array}$ & $\begin{array}{c}54^{\circ} \pm 45^{\circ} \\
(0.542)\end{array}$ & $\begin{array}{c}48^{\circ} \pm 33^{\circ} \\
(0.623)\end{array}$ & $\begin{array}{c}59^{\circ} \pm 43^{\circ} \\
(0.528)\end{array}$ & $\begin{array}{c}62^{\circ} \pm 41^{\circ} \\
(0.421)\end{array}$ \\
\hline number & $3.8 \pm 4.2$ & $6.2 \pm 2.1$ & $5.7 \pm 4.2$ & $5.9 \pm 3.1$ & $5.1 \pm 3.8$ & $5.2 \pm 6.1$ & $6.1 \pm 2.2$ & $4.9 \pm 5.1$ \\
\hline
\end{tabular}

M. scutellaris and in $28 \%$ in M. quadrifasciata). Clockwise and counterclockwise rotation occurred equally often. We also calculated the rotation angle $(N=7, n=91$ for M. scutellaris; $N=6, n=58$ for $M$. quadrifasciata) and compared it with the distance and the direction of the food source. But again no significant correlations emerged $(p>0.05$, Tab. II).

\subsubsection{Recruited bees}

Because we had marked the majority of the bees in the recording box the day before each experiment we were able to recognize them individually on our video tapes. Thus we could observe the behavior of individually marked recruits before they left the hive and were collected at the experimental feeder. In the following we will refer to these bees as prospective recruits.

The following behavioral parameters were analyzed in 21 different prospective recruits of $M$. quadrifasciata: direct contact with foragers, defined as an active movement of the recruit towards the forager leading to body contact; food contact, when a prospective recruit takes a food sample directly from a forager or from a hive bee that in turn had taken it from a forager bee; leaving the recording box through the entrance as a measure for the number of hive exits preceding the flight to the experimental feeder.

Prospective recruits do not have any kind of contact with foragers until about one hour before they leave the hive for the food source. They show maximum "interest" in the food about 20 minutes before leaving and after that they show maximum "interest" in the forager (Fig. 6). We compared the number of contacts of prospective recruits and of randomly chosen hive bees at the head region and at the thoracic and abdominal region of foragers. In both species prospective recruits (24 of $M$. scutellaris and 43 of $M$. quadrifasciata) preferably first contact the thorax and abdomen of a forager whereas hive bees first contact the head region (Fig. 7). The difference between the contacting behavior of recruits and hive bees is highly significant ( $p<0.01$, chi-squaretest).

To see if recruits might be directly guided to a food source by a forager we observed the hive leaving behavior of prospective recruits. In only $7(8 \%)$ out of 58 observed cases foragers left the recording box together with a prospective recruit. Some of the prospective recruits never left the hive before flying to the experimental feeder. The mean number of hive exits of prospective recruits before leaving to the food source is 0.7 $( \pm 0.2)$. 
Table II. On the spot rotations by a forager after having unloaded food in relation to the distance and the direction of a food source from the hive. The values given are the angle (and the radius) of the mean difference vector (difference between original and final position of the bee) \pm 1 SD. (A) For M. scutellaris we analyzed turns for food distances of $30 \mathbf{~ m}(N=2, n=4), \mathbf{7 0 ~} \mathbf{m}(N=3, n=29)$ and $140 \mathbf{m}(N=2, n=5)$ and for food directions southeast $(N=3, n=27)$, south $(N=3, n=10)$ and south-west $(N=3, n=16)$. (B) For M. quadrifasciata we analyzed turns for food distances of $10 \mathrm{~m}$ $(N=2, n=4), \mathbf{3 0} \mathbf{~ m}(N=3, n=10), \mathbf{4 5} \mathbf{~ m}(N=2, n=5), \mathbf{7 0} \mathbf{~ m}(N=4, n=5)$ and $\mathbf{1 4 0} \mathbf{~ m}(N=3, n=6)$ and for food directions north-west $(N=2, n=9)$, west $(N=4, n=13)$ and south-east $(N=2, n=6)$. The amount of turning does not significantly correlate with either distance or direction of the food source $(p>0.05)$.

\begin{tabular}{|c|c|c|c|c|c|c|}
\hline \multicolumn{7}{|c|}{ A-Melipona scutellaris } \\
\hline \multirow{2}{*}{$\begin{array}{l}\text { rotation } \\
\text { angle }\end{array}$} & \multicolumn{3}{|c|}{ distance to food source } & \multicolumn{3}{|c|}{ direction to food source } \\
\hline & $30 \mathrm{~m}$ & $70 \mathrm{~m}$ & $140 \mathrm{~m}$ & SE & $\mathrm{S}$ & SW \\
\hline Melipona scutellaris & $\begin{array}{c}312^{\circ} \pm 57^{\circ} \\
(0.501)\end{array}$ & $\begin{array}{c}332^{\circ} \pm 39^{\circ} \\
(0.775)\end{array}$ & $\begin{array}{c}351^{\circ} \pm 33^{\circ} \\
(0.839)\end{array}$ & $\begin{array}{c}326^{\circ} \pm 50^{\circ} \\
(0.622)\end{array}$ & $\begin{array}{c}357^{\circ} \pm 49^{\circ} \\
(0.634)\end{array}$ & $\begin{array}{c}341^{\circ} \pm 45^{\circ} \\
(0.691)\end{array}$ \\
\hline
\end{tabular}

\section{B-Melipona quadrifasciata}

\begin{tabular}{|c|c|c|c|c|c|c|c|c|}
\hline \multirow{2}{*}{$\begin{array}{l}\text { rotation } \\
\text { angle }\end{array}$} & \multicolumn{5}{|c|}{ distance to food source } & \multicolumn{3}{|c|}{ direction to food source } \\
\hline & $10 \mathrm{~m}$ & $30 \mathrm{~m}$ & $45 \mathrm{~m}$ & $70 \mathrm{~m}$ & $140 \mathrm{~m}$ & NW & S & SE \\
\hline Melipona quadrifasciata & $\begin{array}{c}321^{\circ} \pm 65^{\circ} \\
(0.302)\end{array}$ & $\begin{array}{c}352^{\circ} \pm 45^{\circ} \\
(0.235)\end{array}$ & $\begin{array}{c}334^{\circ} \pm 35^{\circ} \\
(0.146)\end{array}$ & $\begin{array}{c}342^{\circ} \pm 37^{\circ} \\
(0.354)\end{array}$ & $\begin{array}{c}319^{\circ} \pm 56^{\circ} \\
(0.279)\end{array}$ & $\begin{array}{c}356^{\circ} \pm 32^{\circ} \\
(0.425)\end{array}$ & $\begin{array}{c}345^{\circ} \pm 45^{\circ} \\
(0.217)\end{array}$ & $\begin{array}{c}352^{\circ} \pm 36^{\circ} \\
(0.316)\end{array}$ \\
\hline
\end{tabular}



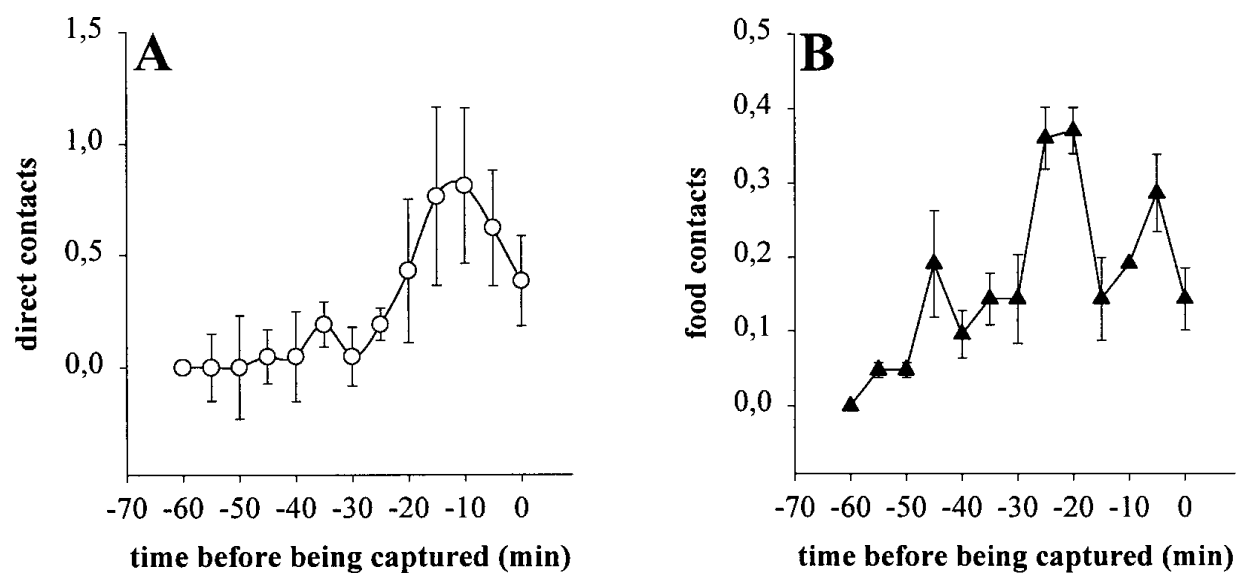

Figure 6. A direct contacts (body contacts with a forager) and $\mathbf{B}$ food contacts (mean $\pm 1 \mathrm{SD}$ ) of prospective recruits of $M$. quadrifasciata before leaving the hive for a food source. Time 0 indicates the time when a recruit is captured at the food source.

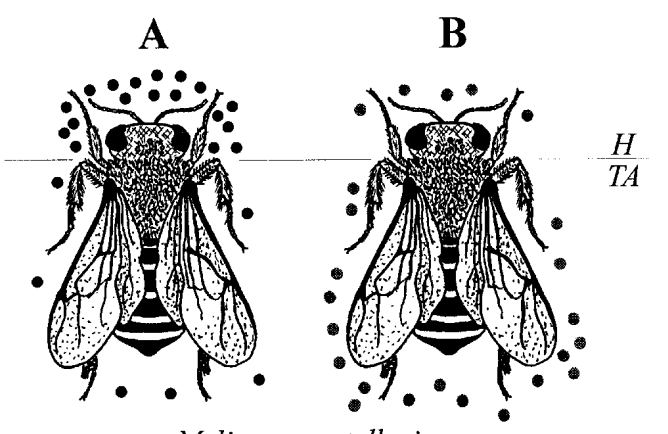

Melipona scutellaris

D
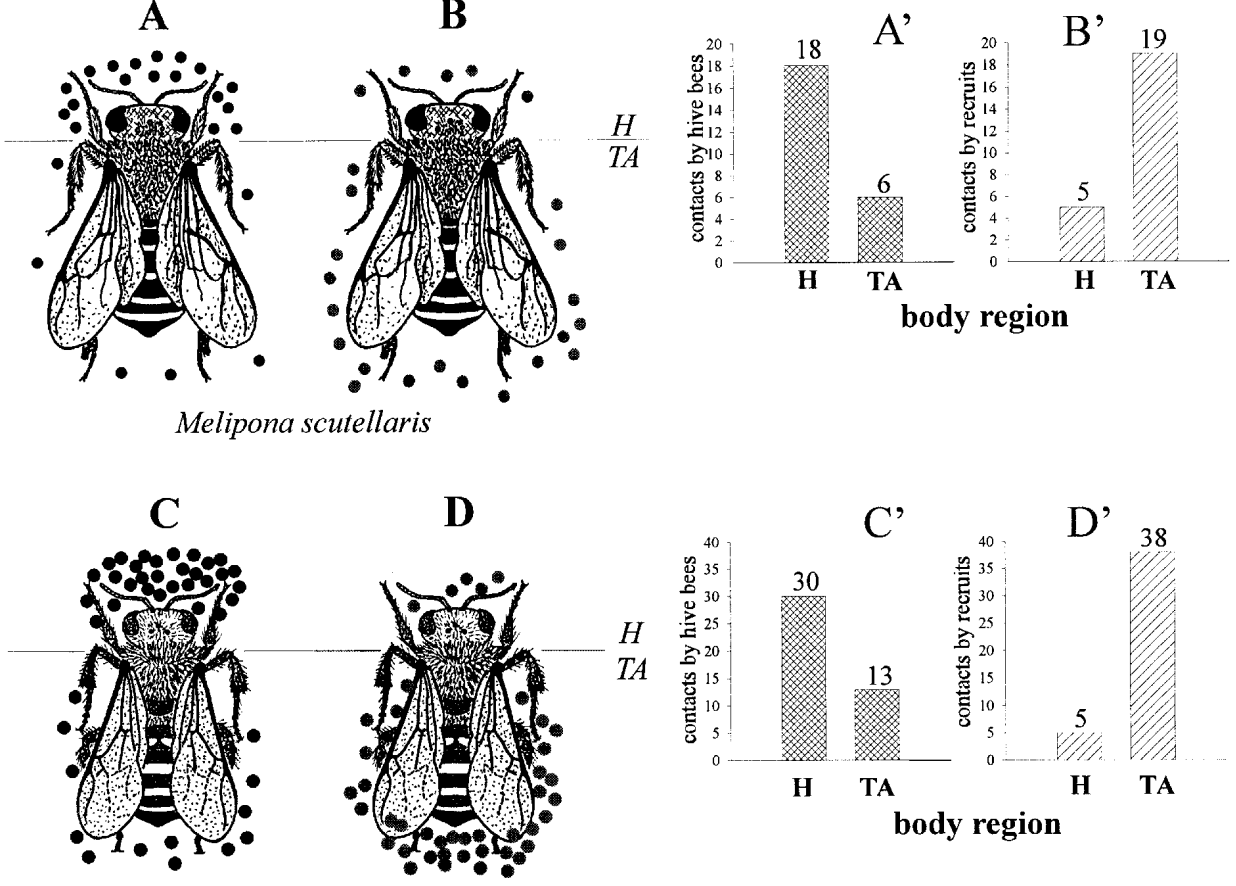

Melipona quadrifasciata

Figure 7. First contacts of hive bees and prospective recruits with a successful forager. A, A' 24 randomly chosen hive bees of $M$. scutellaris, B, B' 24 prospective recruits of M. scutellaris, C, C' 43 randomly chosen hive bees of $M$. quadrifasciata, D, D' 43 prospective recruits of $M$. quadrifasciata. The black dots around the bees (the foragers) represent the heads of the contacting bees. $\mathbf{H}$ head region of forager, TA thoracic-abdominal region of forager. 


\subsection{Airborne sound and substrate vibration}

When a successful forager returned to the hive it produced sounds which were audible even to the human ear. These sounds were composed of single sound pulses.

\subsubsection{Melipona scutellaris}

Foragers started producing sounds while entering the hive. This entry sound often was one long continuous single pulse. When starting to unload food the forager sound changed to short, intermitted pulses that continued after the unloading phase. In $39 \%$ of the observations the sounds differed from this scheme with either short pulsed entry sounds or long pulses during the unloading of food.

\subsubsection{M. quadrifasciata}

There was no continuous entry sound like in M. scutellaris. The foragers immediately started with short intermitted pulses. In only $24 \%$ of the observed cases sound production already started before unloading food and in $84 \%$ it continued afterwards (Fig. 8).

We only analyzed those signals that could be attributed to an individually identified forager (i.e. when only one forager was in the recording box). Taking the transmission properties of the cardboard bottom (see introduction - recording box) into consid- eration we analyzed only forager signals produced at those locations in the recording box (i.e. near its center) where the distorting effect of the cardboard bottom was found to be minimal (Fig. 2).

The five signal parameters we analyzed were (i) the signal duration, (ii) the number of single pulses, (iii) the duration of these single pulses, (iv) the duration of the intervals between the single pulses and (v) the main frequencies contained in the signal (Figs. 9 and 10). We tested the relationship between these parameters and both the distance and the direction of the food source from the hive.

For neither species a significant correlation was found between any of the above mentioned signal parameters (i-v) and the distance or the direction of the food source. We find a statistically significant difference ( $p<0.05$, Krustal-Wallis 1-Way Anova) between the values for the duration of single pulses and intervals at different distances and between the main frequency components at different distances and directions in M. scutellaris and M. quadrifasciata. However, because there is no systematic relation any importance of these differences for the communication of distance or direction is doubtful. Mean values, standard deviations and correlation coefficients of the various parameter values are shown in Table III for M. scutellaris and M. quadrifasciata.
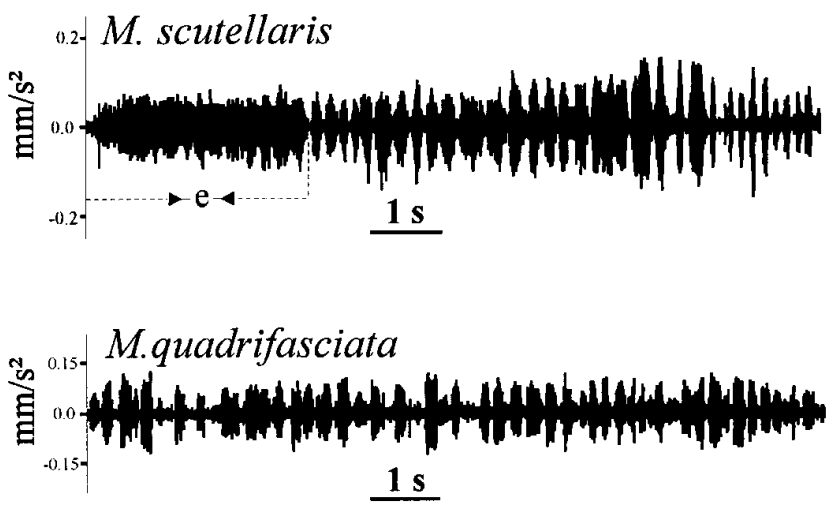

Figure 8. Substrate vibrations produced by foragers of $M$. scutellaris and M. quadrifasciata. Foragers of M. scutellaris start producing sounds while entering the hive. A long, continuosus entry sound (e) is followed by intermitted pulses. Foragers of M. quadrifasciata immediately start with intermitted pulses. 
Figure 9. Substrate vibration produced by a forager of M. scutellaris (collecting at a food source $30 \mathrm{~m}$ southwest of the hive) within the registration box. Top: the entire signal; bottom: expanded part of upper signal showing single pulses.

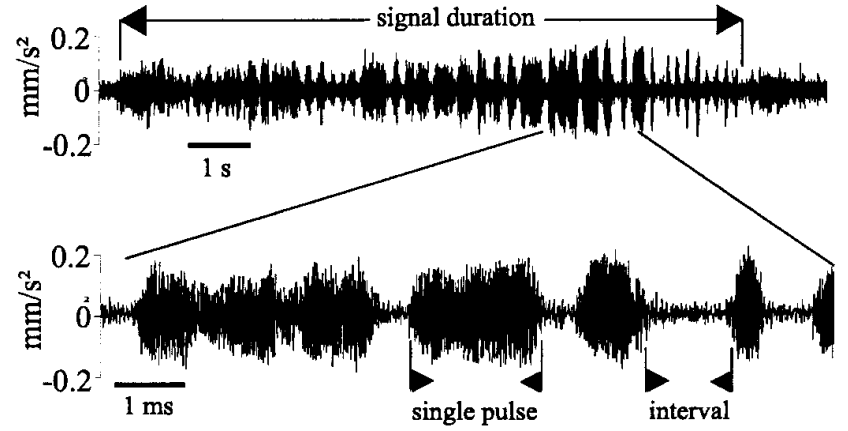

A

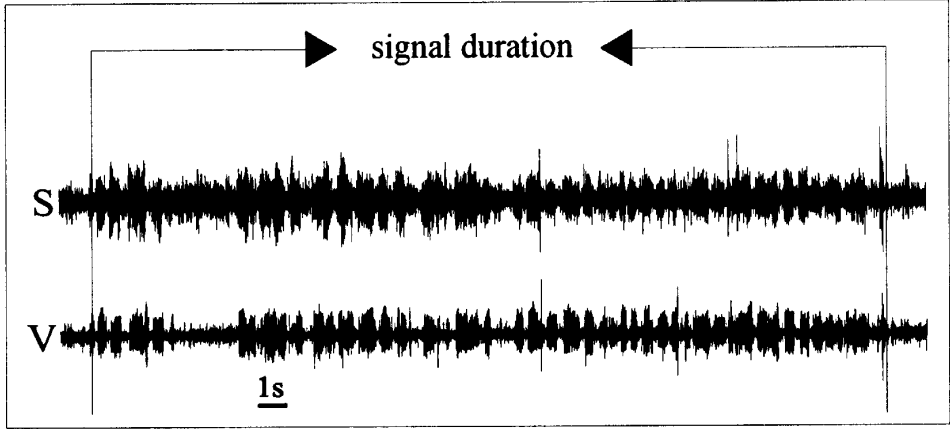

B

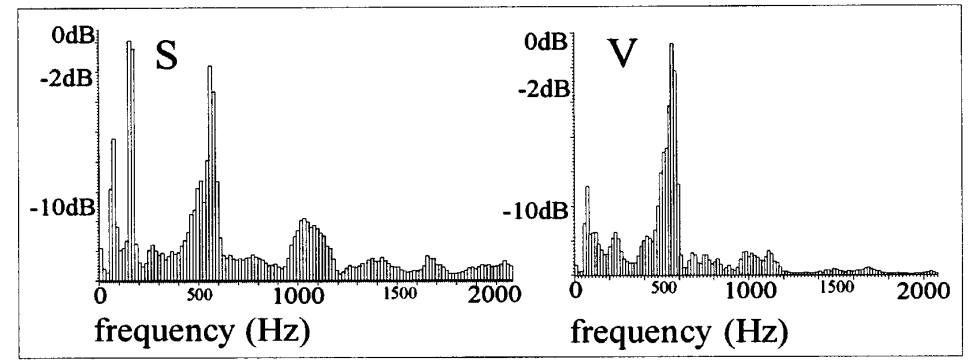

Figure 10. A airborne sound $(\mathbf{S})$ and simultaneously recorded substrate vibration $(\mathbf{V})$ produced by a forager of $M$. quadrifasciata, collecting at a food source $30 \mathrm{~m}$ southeast of the hive. $\mathbf{B}$ frequency spectra of the signals in A. C highest frequency peaks in individual pulses $(\bigcirc$ for sound frequencies, $\nabla$ for vibration frequencies) during the entire signal. The hatched area marks the background noise.

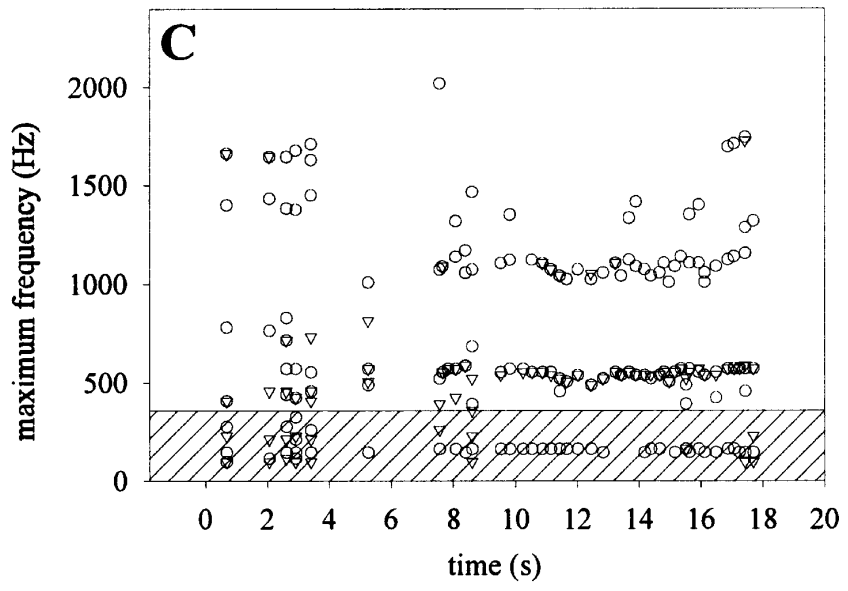


The large variation found in the signal structure of bees collecting at the same food source is reflected by large standard deviations in both species and demonstrated in Figure 11, taking a forager of $M$. scutellaris as a representative example.

The frequency spectrum of the signals shows up to three peaks. The main signal frequency in $M$. scutellaris is between 350 and $520 \mathrm{~Hz}$, in $M$. quadrifasciata it ranges from 480 up to $600 \mathrm{~Hz}$. The two other peaks in the spectrum are higher harmonics of the main frequency. Other frequencies in the spectrum are caused by other bees, which for example hum to cool the hive or warm up their flight muscles. Most of these frequencies are below $350 \mathrm{~Hz}$. We describe them as background noise.

The main frequencies contained in the vibrations vary considerably even for the same location of the food and the same forager. They neither correlate with the distance nor with the direction of the food source.

Airborne sound and substrate vibration of a signal do not differ in any of the signal parameters (an example for M. quadrifasciata is shown in Tab. IV). We found more low frequencies $(<350 \mathrm{~Hz})$ in airborne sound than in substrate vibration. These frequencies are background noise generated by bees inside the hive (hive cooling). Also, the harmonics of a signal's main frequency are more obvious in airborne sound than in substrate vibration. These frequencies are often attenuated by the cardboard bottom of the recording box in substrate vibration, depending on the position of the signaling bee (see example in Fig. 10B).

\section{DISCUSSION}

\subsection{Recruitment by jostling}

On entering the hive foragers of $M$. quadrifasciata show a behavior rather loosely described by Lindauer and Kerr [10] as "agitated running" and "jostling". The "jostling run" we describe in the present study confirms this finding for M. quadrifasciata and extends it to M. scutellaris. According to Jarau et al. [5] non-directional recruitment goes through a maximum during the first 30 minutes in M. scutellaris and $M$. quadrifasciata. In the present study we found maximum jostling activity in the same period of time. Indeed, the mean number of jostles in 5 minute periods correlates with the number of bees alarmed at the same time (collecting bees at the feeder and the control feeder, exponentially rising regression, $r=0.81$; Fig. 12) suggesting that jostling is a mechanism to indicate the existence of a rich food source and to motivate forager bees to search for food at random.

Like Nieh [13] we did not find any correlation between the foragers' movements within the hive and the distance or the direction of the food source. We therefore consider it misleading to call this behavior "recruitment dance" [13] thereby suggesting an unproven relationship to the dance language of the honeybees.

\subsection{Neither zigzag nor guiding flights}

Contrary to the findings reported by Esch [2] for M. quadrifasciata and M. merillae but similar to those reported by Nieh and Roubik [15] for $M$. panamica we failed to observe zigzag flights of foragers in front of the nest entrance and in its near surroundings in $M$. scutellaris and M. quadrifasciata. Judging from our experiments the possibility of "personal" guidance of recruits by foragers is very low indeed as foragers and prospective recruits left the hive together in only $8 \%$ of the observations. Also, prospective recruits left the hive never more than once $(0.7 \pm 0.2)$ before they flew out for a food source. Repeated guiding flights as proposed by Esch [2] for M. quadrifasciata and $M$. merillae are therefore to be excluded as the mechanism to indicate direction in our experiments. Esch found 20 to 30 guiding flights towards a food source until a recruit actually reached it. We have no 
Table III. Properties of a vibration signal produced by a successful forager within the hive and their relationship to the distance and the direction to a food source. All values are means $( \pm 1 \mathrm{SD})$. The parameters analyzed are (1) the signal duration, (2) the number of single pulses, (3) the duration of these single pulses, (4) the duration of the intervals between single pulses and (5) the main frequency component of the signal. (A) For M. scutellaris we analyzed signals for food distances $30 \mathbf{m}(N=2, n=3, s p=39), \mathbf{7 0} \mathbf{~ m}(N=1, n=3, s p=125)$ and $\mathbf{1 4 0} \mathbf{~ m}(N=1, n=2, s p=79)$ and for the directions southeast $(N=3, n=4, s p=117)$, south $(N=3, n=7, s p=88)$ and south-west $(N=2, n=7, s p=209)$. (B) For $M$. quadrifasciata we analyzed signals for food distances $10 \mathbf{~ m}(N=2, n=5, s p=230), \mathbf{3 0} \mathbf{~ m}(N=6, n=15, s p=537), \mathbf{4 5} \mathbf{~ m}(N=2, n=4, \mathrm{sp}=118), \mathbf{7 0} \mathbf{~ m}(N=4, n=7, s p=241)$ and $\mathbf{1 4 0} \mathbf{~ m}$ $(N=3, n=6, s p=237)$ and for the dition

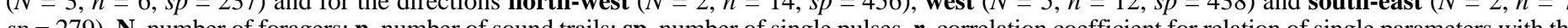
ber of sound trails; $\mathbf{s p}$, number of single pulses. $\mathbf{r}$, correlation coefficient for relation of single parameters with the distance/direction to the food source.

\begin{tabular}{|c|c|c|c|c|c|c|c|c|c|c|c|c|}
\hline \multirow{2}{*}{$\begin{array}{l}\text { A - Melipona scutellaris } \\
\text { signal } \\
\text { parameters }\end{array}$} & \multicolumn{6}{|c|}{ distance to food source } & \multicolumn{6}{|c|}{ direction to food source } \\
\hline & $30 \mathrm{~m}$ & \multicolumn{2}{|c|}{$70 \mathrm{~m}$} & \multicolumn{2}{|c|}{$140 \mathrm{~m}$} & \multicolumn{2}{|l|}{$r$} & $\mathrm{SE}$ & \multicolumn{2}{|c|}{$\mathrm{S}$} & SW & $r$ \\
\hline signal duration (s) & $14.7( \pm 2.2)$ & \multicolumn{2}{|c|}{$12.5( \pm 1.3)$} & \multicolumn{2}{|c|}{$17.2( \pm 2.8)$} & 0.15 & & \multicolumn{2}{|c|}{$10.9( \pm 1.9)$} & $12.3( \pm 1.5)$ & 0.10 \\
\hline $\begin{array}{l}\text { number of pulses } \\
\text { duration of }\end{array}$ & $35.17( \pm 12.2)$ & \multicolumn{2}{|c|}{$27.22( \pm 17.01)$} & \multicolumn{2}{|c|}{$31.01( \pm 9.47)$} & 0.14 & \multicolumn{2}{|r|}{$39.03( \pm 18.3)$} & \multicolumn{2}{|c|}{$34.19( \pm 12.01)$} & $31.07( \pm 10.09)$ & 0.20 \\
\hline single pulses (s) & $0.2( \pm 0.16)$ & \multirow{2}{*}{\multicolumn{2}{|c|}{$\begin{array}{l}0.16( \pm 0.15) \\
0.13( \pm 0.09)\end{array}$}} & \multicolumn{2}{|c|}{$0.2( \pm 0.18)$} & -0.02 & \multicolumn{2}{|r|}{$0,20( \pm 0.18)$} & \multicolumn{2}{|c|}{$0.22( \pm 0.18)$} & $0.21( \pm 0.18)$ & -0.02 \\
\hline duration of intervals (s) & $0.11( \pm 0.11)$ & & & \multicolumn{2}{|c|}{$0.09( \pm 0.06)$} & -0.14 & \multicolumn{2}{|r|}{$0.09( \pm 0.06)$} & \multicolumn{2}{|c|}{$0.08( \pm 0.06)$} & $0.11( \pm 0.11)$ & 0.04 \\
\hline main frequency $(\mathrm{Hz})$ & $432( \pm 56)$ & \multicolumn{2}{|c|}{$501( \pm 22)$} & \multicolumn{2}{|c|}{$493( \pm 54)$} & 0.13 & \multicolumn{2}{|r|}{$453( \pm 49)$} & \multicolumn{2}{|c|}{$397( \pm 50)$} & $395( \pm 35)$ & -0.03 \\
\hline \multicolumn{2}{|c|}{$\begin{array}{l}\text { B - Melipona quadrifasciata } \\
\text { signal }\end{array}$} & & stance & e to fo & d source & & & & & rection to & to food source & \\
\hline parameters & $10 \mathrm{~m}$ & $30 \mathrm{~m}$ & & $\mathrm{~m}$ & $70 \mathrm{~m}$ & $140 \mathrm{~m}$ & $r$ & & NW & W & SE & $r$ \\
\hline signal duration (s) & $\begin{array}{c}12.52 \\
( \pm 1.40)\end{array}$ & $\begin{array}{c}15.17 \\
( \pm 3.81)\end{array}$ & & $\begin{array}{l}.79 \\
7.92)\end{array}$ & $\begin{array}{c}11.72 \\
( \pm 1.51)\end{array}$ & $\begin{array}{c}12.82 \\
( \pm 3.23)\end{array}$ & -0.17 & & $\begin{array}{c}13.06 \\
( \pm 4.11)\end{array}$ & $\begin{array}{l}14.41 \\
( \pm 6.6)\end{array}$ & $\begin{array}{c}12.08 \\
( \pm 2.12)\end{array}$ & -0.05 \\
\hline number of pulses & $\begin{array}{c}34,33 \\
( \pm 25.03)\end{array}$ & $\begin{array}{c}29.53 \\
( \pm 14.03)\end{array}$ & $\begin{array}{r}33 \\
( \pm 5 .\end{array}$ & $\begin{array}{l}3.0 \\
5.66)\end{array}$ & $\begin{array}{c}34.71 \\
( \pm 8.42)\end{array}$ & $\begin{array}{c}39.83 \\
( \pm 16.20)\end{array}$ & 0.24 & & $\begin{array}{c}33.50 \\
( \pm 10.06)\end{array}$ & $\begin{array}{c}34.25 \\
( \pm 12.94\end{array}$ & $\begin{array}{c}39.71 \\
( \pm 11.32)\end{array}$ & 0.20 \\
\hline $\begin{array}{l}\text { duration of } \\
\text { single pulses (s) }\end{array}$ & $\begin{array}{c}0.16 \\
( \pm 0.31)\end{array}$ & $\begin{array}{c}0.29 \\
( \pm 0.54)\end{array}$ & $\begin{array}{r}0.3 \\
\pm 0 .\end{array}$ & $\begin{array}{l}36 \\
.82)\end{array}$ & $\begin{array}{c}0.22 \\
( \pm 0.23)\end{array}$ & $\begin{array}{c}0.18 \\
( \pm 0.26)\end{array}$ & -0.04 & & $\begin{array}{c}0.24 \\
( \pm 0.5)\end{array}$ & $\begin{array}{c}0.21 \\
( \pm 0.27)\end{array}$ & $\begin{array}{c}0.19 \\
( \pm 0.22)\end{array}$ & -0.05 \\
\hline duration of intervals (s) & $\begin{array}{c}0.15 \\
( \pm 0.23)\end{array}$ & $\begin{array}{c}0.16 \\
( \pm 0.26)\end{array}$ & $\begin{array}{r}0 . \\
\pm 0 .\end{array}$ & $.17)$ & $\begin{array}{c}0.11 \\
( \pm 0.14)\end{array}$ & $\begin{array}{c}0.11 \\
( \pm 0.18)\end{array}$ & -0.08 & & $\begin{array}{c}0.12 \\
( \pm 0.18)\end{array}$ & $\begin{array}{c}0.16 \\
( \pm 0.29)\end{array}$ & $\begin{array}{c}0.11 \\
( \pm 0.16)\end{array}$ & 0.00 \\
\hline main frequency $(\mathrm{Hz})$ & $\begin{array}{c}553 \\
( \pm 33)\end{array}$ & $\begin{array}{c}566 \\
( \pm 53)\end{array}$ & & $\begin{array}{l}46 \\
60)\end{array}$ & $\begin{array}{c}562 \\
( \pm 34)\end{array}$ & $\begin{array}{c}496 \\
( \pm 55)\end{array}$ & -0.30 & & $\begin{array}{c}551 \\
( \pm 41)\end{array}$ & $\begin{array}{c}520 \\
( \pm 61)\end{array}$ & $\begin{array}{c}593 \\
( \pm 32)\end{array}$ & 0.23 \\
\hline
\end{tabular}



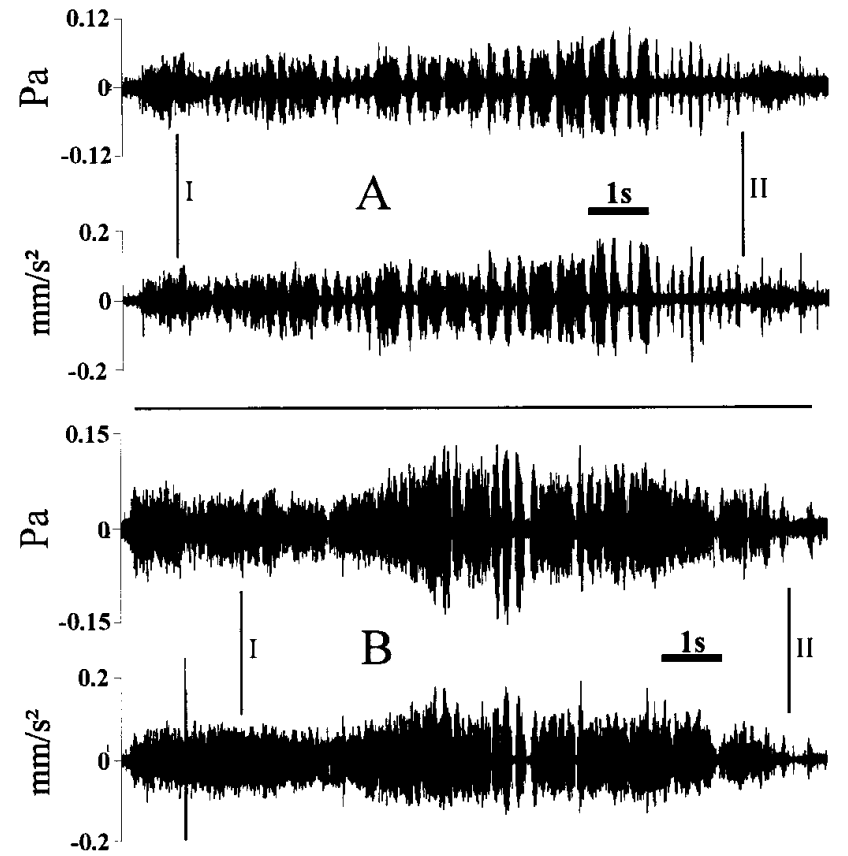

Figure 11. Variability of the mechanical signals (top airborne sound, bottom substrate vibration): $\mathbf{A}$ and B signals produced by the same forager of M. scutellaris, collecting at a food source $30 \mathrm{~m}$ southwest of the hive. I and II beginning and end of the signal, respectively.

Table IV. Difference in the properties of airborne sound and simultaneously recorded substrate vibrations produced by a forager of $M$. quadrifasciata feeding 30 meters southeast of the hive. The values given are the mean $( \pm 1 \mathrm{SD}) . p$ is the probability of a significant difference (STUDENT- $t$-test, $p=1$ when there is no difference) of the values for identical parameters between airborne sound and substrate vibration. Signal duration (12.86 s) and number of pulses (46) are identical for airborne sound and substrate vibration.

pulse duration (s) interval duration (s) main frequency (Hz) first harmonic $(\mathrm{Hz})$

\begin{tabular}{lcccc}
\hline airborne sound & $0.172( \pm 0.154)$ & $0.116( \pm 0.128)$ & $563( \pm 22)$ & $1118( \pm 40)$ \\
substrate vibration & $0.162( \pm 0.131)$ & $0.113( \pm 0.126)$ & $566( \pm 24)$ & $1098( \pm 49)$ \\
$p$ & 0.75 & 0.92 & 0.63 & 0.30 \\
\hline
\end{tabular}

explanation for the discrepancy with our findings.

\subsection{The unimportance of scent marking}

Although we cannot exclude that foragers that interrupted their way home on a bush or any other structure near the feeder did deposit a scent mark, the frequency of this behavior (15 observations for M. scutellaris,
37 for M. quadrifasciata out of about 6000 approaches of foragers for each species, comprising $0.25 \%$ and $0.62 \%$, respectively) was much too low to be of any obvious significance for the guidance of the bees to the food source. In contradiction to our findings Kerr [7] found foragers of M. scutellaris, M. quadrifasciata and M. bicolor to possess a communication system consisting of a small trail of one, two or three scent 


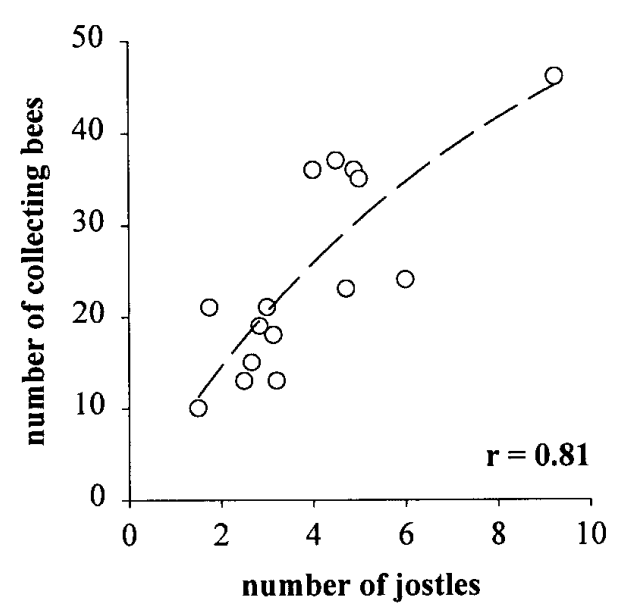

Figure 12. Increase of the alarming success with the amount of jostling. Ordinate: total number of collecting bees captured at the feeder and control feeder in the recruitment experiments by Jarau et al. [5]. Abscissa: mean number of jostles at the time interval when also the recruits were captured. Note the exponential increase of the recruitment success with the number of jostles $(r=0.81)$.

marks. Kerr and Rocha [8] made similar observations for $M$. ruviventris and M. compressipes. However, the meaning of such scent marks in communication was not examined in either paper, nor did they mention if other foragers were attracted by these marks. Furthermore, in M. scutellaris, M. quadrifasciata and M. bicolor all marks occurred within $7.5 \mathrm{~m}$ of the food source (majority within $4 \mathrm{~m}$ ) when the feeder was placed at a distance of $20 \mathrm{~m}$ from the hive [7] and in M. ruviventris and M. compressipes all marks occurred within $8 \mathrm{~m}$ (on average $4 \mathrm{~m}$ ) of the feeder, even if its distance from the hive was $100 \mathrm{~m}$ [8]. At such close distances scent marks may be used by newcomers to orient towards a food source at its final position, but they do not provide a scent trail followed by recruits from the nest to the food. Nieh [12] recently found that foragers of $M$. panamica can deposit a scent beacon that influences the orientation of other bees near the food source (6-12 m).

\subsection{Contacting behavior of prospective recruits}

Individual marking of the majority of the bees in the recording box on the day preceding the experiment enabled us to analyze for the first time the behavior of the bees within the hive (i.e. the recording box) before they left for the food source.

The prospective recruits do not have contact with the food from the food source or with the foragers collecting there until one hour before being captured at the feeder. We propose that the recruits first try to get information about the quality of the food by taking up samples (maximum food contact 20 minutes before being captured). They then try to get information about the location of the food source by contacting the forager (maximum direct contact 10 minutes before being captured).

Prospective recruits of $M$. scutellaris and M. quadrifasciata preferably contact a successful forager at the thoracic-abdominal region. Michelsen et al. [11] described this region as that part of the acoustic near field of waggle dancing honeybees (Apis mellifera) where air particle movements are most intense. Nieh [13] showed that nestmates of $M$. panamica preferably contact the thoracic abdominal region of a forager when a food source offers food with sugar in high concentration.

\subsection{Airborne sound and substrate vibration}

In both M. scutellaris and M. quadrifasciata the properties of the sound and vibrational signals produced by foragers returning from a rich food source vary to a large extent. This leads us to seriously doubt whether there is any information about the location of a food source contained in these signals. We compared our findings with results from the literature for similar distances. Nieh and Roubik [15] suggest that $M$. panamica uses the duration of the pulses produced during the unloading of food to 
communicate the height of a food source and the duration of pulses produced after the unloading of food ("dance sounds") to communicate food distance. The "longest dance pulse" rises from $0.23 \mathrm{~s}$ at a food source distance of $0 \mathrm{~m}$ up to $1.86 \mathrm{~s}$ at a 360 m. However, the variation (i.e. the standard

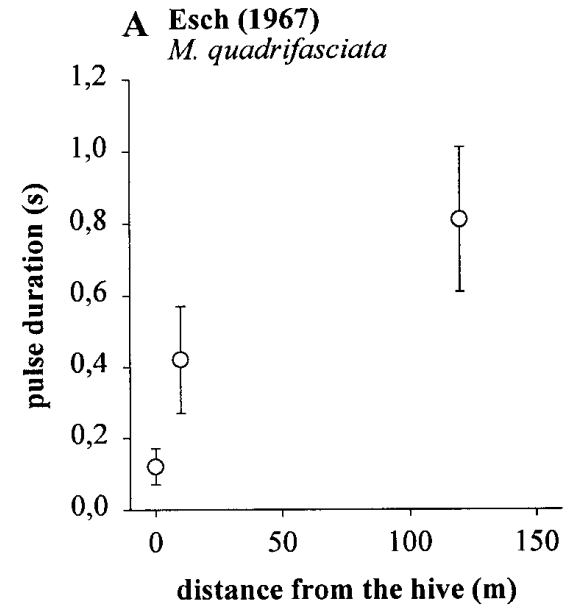

C M. scutellaris

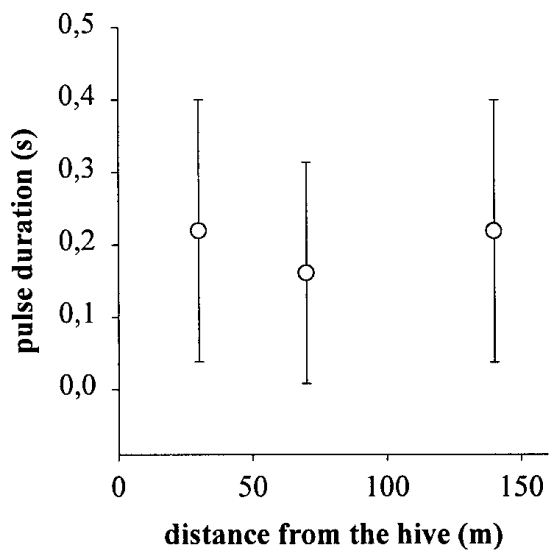

deviation) in their data is too high (Fig. 13) to reasonably explain the accuracy found in the three dimensional communication of this species [14].

Esch [2] was the first to tape sound signals of foragers of $M$. quadrifasciata returning from a food source at distances between

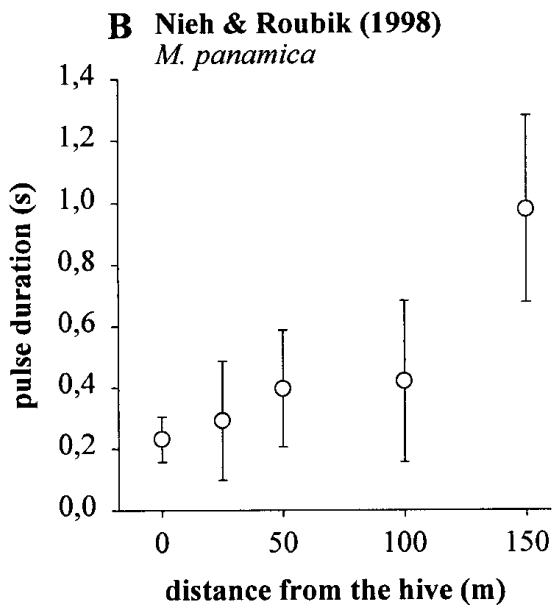

D M. quadrifasciata

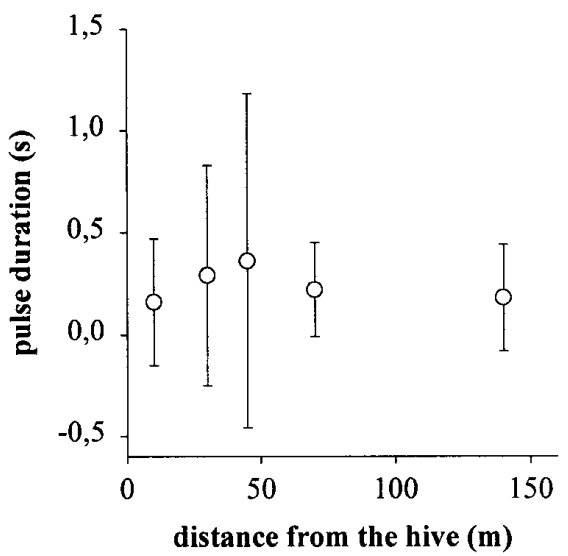

Figure 13. Correlating sound/vibration duration with distance to food source; comparison of the results obtained by (A) Esch [2] for M. quadrifasciata (each value is the average of 960-2045 single pulses), by (B) Nieh \& Roubik [15] for M. panamica (4-26 single pulses) and by the present study for (C) M. scutellaris (39-125 single pulses) and (D) M. quadrifasciata (118-537 single pulses). Ordinate: duration of the single pulses (mean $\pm 1 \mathrm{SD}$ ) of a mechanical signal. Abscissa: distance of the food source from the hive. 
$0 \mathrm{~m}$ and $700 \mathrm{~m}$. Judging from the sonogram he presents in his study these are obviously the same single pulsed signals we found in M. quadrifasciata and also in M. scutellaris. In the experiments of Esch [2] pulse duration increased with food distance in particular at relatively small distances (steepest slope of curve). Thus it was $0.12 \mathrm{~s}$ when the food was directly at the hive entrance and $0.81 \mathrm{~s}$ when it was $120 \mathrm{~m}$ away. These findings were the reason for us to concentrate our experiments on smaller distances. Despite the large variability in the data of Esch [2] similar to that in our findings, the increase of pulse duration with distance is statistically significant. At distances larger than $120 \mathrm{~m}$ (measurements up to $700 \mathrm{~m}$ ), however, variation further increased and it is hard to imagine how the bees can successfully deal with this [2]. In our study the mean duration of single pulses never exceeded $0.36 \mathrm{~s}$ in $M$. quadrifasciata. The reason for the discrepancy between our data and those of Esch [2] is unclear.

Sound signals of foragers produced by flight muscles [2] are also transmitted as substrate vibrations. Lindauer and Kerr [10] showed that these vibrations alarm hive bees of $M$. scutellaris and induce their flight to a food source. Although they only describe the signals produced by foragers verbally as rhythmically intermitted sounds, these signals are likely the same signals we found in our study. Honeybees (Apis mellifera) use their subgenual organ (a chordotonal organ in the tibia of each leg) to detect vibrations [1]. This vibration receptor is most sensitive for vibrations around $350-500 \mathrm{~Hz}$ [9] with response thresholds between 0.1 and $0.3 \mathrm{~mm} / \mathrm{s}$. There are no studies on vibration sensitive organs in Melipona. However, the frequencies we found may be within the range of the bees' sensitivity. The acceleration values measured by us were in the range of up to about $0.2 \mathrm{~mm} / \mathrm{s}^{2}$ ).

\section{ACKNOWLEDGEMENTS}

We would like to thank Warwick E. Kerr, who kindly provided the colony of Melipona scutellaris from his private meliponary in Uberlândia - MG. We are also grateful to Sidney Mateus for his help in handling the bees. This work was partly supported by a grant from the BMFWK of Austria to MH and SJ and by money made available to FGB by the Convenio between the University of São Paulo and the University of Vienna.

Résumé - Comportement de recrutement chez les abeilles sans aiguillon, Melipona scutellaris et Melipona quadrifasciata. II. Mécanismes éventuels de communication. Afin d'élucider ce que font réellement les abeilles sans aiguillon Melipona scutellaris et Melipona quadrifascita (Hymenoptera, Apidae) lorsqu'elles recrutent des congénères du nid à une source de nourriture, nous avons dressé trois abeilles à venir visiter un nourrisseur situé à diverses distances de la ruche et dans diverses directions. Les butineuses qui rentraient déchargeaient leur nourriture à l'intérieur d'une boîte d'enregistrement installée entre l'entrée du nid et le nid lui-même (Fig. 1). Là, nous avons enregistré en vidéo le comportement des butineuses et leurs interactions avec les abeilles de la ruche et avec les recrues et enregistré simultanément les sons et les vibrations qu'elles produisaient de retour d'un nourrisseur avec un sirop très concentré $\left(1,5 \mathrm{~mol} \cdot \mathrm{l}^{-1}\right)$.

L'analyse des sons et des vibrations a montré que tous les paramètres mesurés (durée du signal, nombre et durée des impulsions, durée des intervalles entre les impulsions et fréquence principale d'un signal ; Figs. 9 et 10) variaient largement (Fig. 11). Contrairement aux résultats de Esch [2] pour $M$. quadrifasciata et $M$. merillae et de Nieh et Roubik [11] pour M. panamica, nous n'avons trouvé aucune corrélation entre les durées des impulsions et la distance à une source de nourriture (Fig. 13). Ni la répartition dans le temps ni les caractéristiques spectrales des signaux ne sont corrélées significativement avec la distance ou la direction du nourrisseur (Tab. III).

Outre l'indication par le son et les vibrations de l'existence d'une source de 
nourriture bien approvisionnée, les butineuses stimulent les recrues à rechercher de la nourriture au hasard à l'aide d'une " course-bousculade » (Fig. 3). Le nombre de bousculades est corrélé au nombre d'abeilles qui s'envolent (Fig. 12).

Lorsqu'elles courent à travers la ruche, les butineuses tournent et changent de direction fréquemment. Pourtant il n'y a pas de « danse » indiquant la localisation de la source de nourriture et aucune corrélation n'a été trouvée entre ces mouvements et soit la distance, soit la direction de la source (Fig. 5 ; Tabs. I et II).

On peut exclure les vols en zig-zag et les vols d'accompagnement des mécanismes qui indiquent la localisation d'une source de nourriture. Les butineuses et les recrues ne quittaient la ruche ensemble que dans $8 \%$ des observations. Les futures recrues ne quittaient jamais la ruche plus d'une fois $(0,7$ $\pm 0,2$ ) avant de s'envoler pour une source de nourriture, où elles étaient capturées. De même la fréquence du marquage olfactif était bien trop faible dans nos expériences pour être utilisé comme moyen de communication de la localisation de la source de nourriture.

Les futures recrues n'entrent en contact avec les butineuses ou avec la nourriture que celles-ci rapportent qu'environ une heure avant leur propre envol. Nos résultats suggèrent que les recrues obtiennent $d$ 'abord une information sur la qualité de la nourriture (nombre maximum de contacts alimentaires 20 minutes avant leur capture), puis une information sur la localisation de la source (nombre maximum de contacts directs avec les butineuses environ 10 minutes avant leur capture, Fig. 6).

Lorsque les futures recrues de M. scutellaris et $M$. quadrifasciata établissent le contact avec une butineuse qui rapporte de la nourriture, c'est de préférence dans la région thorax-abdomen (Fig. 7).

Nous avons donc montré comment l'existence d'une source de nourriture bien approvisionnée était indiquée ; par contre les mécanismes par lesquels les butineuses communiquent la distance et la direction restent toujours obscurs.

Melipona / abeille sans aiguillon / nourriture / recrutement / communication sonore et vibration

Zusammenfassung - Rekrutierungsverhalten bei stachellosen Bienen (Melipona scutellaris und Melipona quadrifasciata). II. Mögliche Mechanismen der Kommunikation. Zur Analyse des Rekrutierungsverhaltens von Sammlerinnen der stachellosen Bienenarten Melipona scutellaris und M. quadrifasciata wurden drei Sammelbienen zu Futterstellen in unterschiedlichen Entfernungen und Richtungen vom Stock dressiert. Heimgekehrte Sammelbienen gaben ihr Futter in einer Registrierbox (Abb. 1), die zwischen dem Ausflugsloch und dem Nest installiert war, an Stockbienen ab. Hier konnten das Verhalten der Sammelbienen sowie ihre Interaktionen mit den Stockbienen auf Video aufgezeichnet und gleichzeitig der von ihnen nach der Rückkehr von einer Futterstelle mit hochkonzentriertem Zuckerwasser $\left(1.5 \mathrm{~mol} \cdot \mathrm{l}^{-1}\right)$ produzierte Luftschall und die Vibrationen registriert werden.

Die Analyse von Luftschall und Vibrationen ergab, da $\beta$ alle vermessenen Parameter (Signaldauer, Anzahl und Dauer der Einzelpulse, Dauer der Intervalle zwischen den Pulsen, sowie die stärkste Frequenzkomponente eines Signals, Abb. 9 und 10) stark variieren (Abb. 11). Im Gegensatz zu den Ergebnissen von Esch [2] bei M. quadrifasciata sowie $M$. merillae und von Nieh und Roubik [15] bei M. panamica konnte in der vorliegenden Arbeit für M. scutellaris und $M$. quadrifasciata keine signifikante Korrelation zwischen der Dauer der Einzelpulse und der Entfernung einer Futterquelle gefunden werden (Abb. 13). Weder das zeitliche Muster noch die Eigenschaften des Frequenzspektrums eines Signals korrelierten signifikant mit der Entfernung oder der 
Richtung der Futterquelle (Tab. III).

Sammelbienen motivieren Rekruten im Stock mit Hilfe eines "Rempel-Laufes" (Abb. 3) zu einer ungerichteten Suche nach der Futterquelle. Die Anzahl der Rempler korreliert mit der Anzahl der ausfliegenden Bienen (Abb. 12).

Laufen Sammelbienen durch den Stock, so drehen sie sich und wechseln häufig ihre Laufrichtung. Von einem "Tanz" zu sprechen, ist jedoch unangebracht, da zwischen diesen Bewegungen und der Entfernung bzw. Richtung einer Futterquelle kein Zusammenhang besteht (Abb. 5, Tab. I und II).

"Zickzack-Flüge" und "Geleitflüge" von Sammelbienen können als Mechanismus zur Anzeige des Ortes einer Futterquelle ausgeschlossen werden: Sammelbienen und Rekruten verließen den Stock in nur $8 \%$ der Beobachtungen gemeinsam und prospektive Rekruten verließen den Stock durchschnittlich weniger als einmal $(0,7 \pm$ 0,2 ), bevor sie eine Futterquelle anflogen und dort abgefangen wurden.

Prospektive Rekruten kommen mit den Sammelbienen und dem von diesen mitgebrachten Futter erst etwa eine Stunde vor ihrem eigenen Ausflug in Kontakt. Unsere Befunde sprechen dafür, dass Rekruten zunächst Information über die Futterqualität sammeln (maximale Zahl der Kontakte mit dem Futter ca. 20 Minuten vor dem Abgefangenwerden), bevor sie dann versuchen, Information über die Lage der Futterquelle selbst zu erhalten (maximale Zahl direkter Kontakte zu den Sammelbienen ca. 10 Minuten vor dem Abgefangenwerden, Abb. 6).

Prospektive Rekruten von M. scutellaris und $M$. quadrifasciata kontaktieren bevorzugt die Thorax-Abdomen-Region einer erfolgreichen Sammelbiene (Abb. 7).

Während durch diese Arbeit die Mechanismen, mit deren Hilfe Sammelbienen die bloße Existenz einer Futterquelle anzeigen, etwas klarer geworden sind, bleiben die Mechanismen der Kommunikation von Entfernung und Richtung einer Futterquelle weiterhin unverstanden. stachellose Bienen / Rekrutierung / Mechanismen der Kommunikation / Luftschall und vibratorische Signale / Melipona

\section{REFERENCES}

[1] Autrum H., Schneider W., Vergleichende Untersuchungen über den Erschütterungssinn der Insekten, Z. Vergl. Physiol. 31 (1948) 77-88.

[2] Esch H., Die Bedeutung der Lauterzeugung für die Verständigung der stachellosen Bienen, Z. Vergl. Physiol. 56 (1967) 199-220.

[3] Esch H., Esch I., Kerr W.E., Sound: an element common to communication of stingless bees and to dances of the honeybee, Science 149 (1965) 320-321.

[4] Frisch K. von, Tanzsprache und Orientierung der Bienen, Springer-Verlag, Berlin, 1965.

[5] Jarau S., Hrncir M., Zucchi R., Barth F.G., Recruitment behavior in stingless bees, Melipona scutellaris and M. quadrifasciata. I. Foraging at food sources differing in direction and distance, Apidologie 31 (2000) 81-91.

[6] Kerr W.E., Some aspects of the evolution of social bees, Evol. Biol. 3 (1969) 119-175.

[7] Kerr W.E., Communication among Melipona workers (Hymenoptera: Apidae), J. Insect Behav. 7 (1994) 123-128.

[8] Kerr W.E., Rocha R., Comunicação em Melipona rufiventris e Melipona compressipes, Ciência e Cultura 40 (1988) 1200-1202.

[9] Kilpinen O., Storm J., Biophysics of the subgenual organ of the honeybee Apis mellifera, J. Comp. Physiol. A 181 (1997) 309-318.

[10] Lindauer M., Kerr W.E., Die gegenseitige Verständigung bei den stachellosen Bienen, Z. Vergl. Physiol. 41 (1958) 405-434.

[11] Michelsen A., Towne W.F., Kirchner W.H., Kryger P., The acoustic near field of a dancing honeybee, J. Comp. Physiol. A 161 (1987) 633-643.

[12] Nieh J.C., The role of a scent beacon in the communication of food location by the stingless bee, Melipona panamica, Behav. Ecol. Sociobiol. 43 (1998) 47-58.

[13] Nieh J.C., The food recruitment dance of the stingless bee, Melipona panamica, Behav. Ecol. Sociobiol. 43 (1998) 133-145.

[14] Nieh J.C., Roubik D.W., A stingless bee (Melipona panamica) indicates food location without using a scent trail, Behav. Ecol. Sociobiol. 37 (1995) 63-70.

[15] Nieh J.C., Roubik D.W., Potential mechanisms for the communication of height and distance by a stingless bee, Melipona panamica, Behav. Ecol. Sociobiol. 43 (1998) 387-399. 